\title{
PREFERENSI PENGENDARA SEPEDA MOTOR TERHADAP PENGGUNAAN HELM SNI DI KOTA MAKASSAR
}

\section{Preference of Motorcycle Riders for the Use of SNI Helmets in Makassar City}

\author{
Muhammad Isran Ramli \\ Departemen Teknik Sipil \\ Universitas Hasanudin \\ Jl. Poros Malino Km. 6, Gowa \\ Sulawesi Selatan \\ isranramli@unhas.ac.id
}

\author{
Muralia Hustim \\ Departemen Teknik Lingkungan \\ Universitas Hasanudin \\ Jl. Poros Malino Km. 6, Gowa \\ Sulawesi Selatan \\ muraliahustim@ft.unhas.ac.id
}

\author{
Mubassirang Pasra \\ Departemen Teknik Sipil \\ Universitas Hasanudin \\ Jl. Poros Malino Km. 6, Gowa \\ Sulawesi Selatan \\ mubassirangpasra@unhas.ac.id
}

\begin{abstract}
The present study aims to investigate the characteristics of motorcyclists in Makassar City, Indonesia, as well as to analyze the motorcyclist's preference in utilizing helmet SNI for both sides, policy, and comfortability. The study conducted data collection in a primary arterial road in the city using the interview survey method based on a questionnaire instrument. We adopted a statistically descriptive, and multi-nomial logit model approach to assess the significance level of the motorcyclist characteristics on their preferences in using helmet SNI. The results show that age and education of the motorcyclists have become two significant variables which influence their preference, not only for policy but also for comfortability in utilizing the helmet. The results provide a piece of basic information which useful in deriving a policy on traffic management measures for the motorcyclist in Makassar City, and generally in Indonesia.
\end{abstract}

Keywords: preference, driver, motorcycle, SNI Helmet, Makassar City.

\begin{abstract}
Abstrak
Studi bertujuan menginvestigasi karakteristik pengendara sepeda motor di Kota Makassar dan menganalisis preferensinya terhadap penggunaan Helm SNI, baik dari sisi kebijakan maupun dari sisi kenyamanannya. Pengumpulan data dilakukan di salah satu ruas jalan arteri utama di di Kota Makassar dengan menggunakan metode survei wawancara berbasis instrument kuesioner. Pendekatan analisis data statistik deskriptif dan lebih jauh mengadopsi pendekatan model multi-nomial logit untuk menilai sejauhmana signifikansi karakteristik pengendara sepeda motor terhadap preferensinya dalam penggunaan Helm SNI. Hasil-hasil analisis memperlihatkan bahwa karakteristik umur dan pendidikan merupakan dua variabel yang cukup signifikan mempengaruhi preferensi pengendara sepeda motor dalam aspek kebijakan dan kenyaman penggunaan Helm SNI. Hasil ini menjadi informasi dan dasar yang cukup penting dalam perumusan upayaupaya pendekatan yang dapat dilakukan terhadap pengguna sepeda motor, baik berupa upaya memassifkan penggunaan Helm SNI di masyarakat, maupun upaya untuk implementasi berbagai aturan tertib berlalu lintas lainnya di Indonesia.
\end{abstract}

Kata Kunci: preferensi, pengendara, sepeda motor, Helm SNI, Kota Makassar.

\section{PENDAHULUAN}

Dalam satu dekade terakhir, pertumbuhan kendaraan bermotor baik kendaraan bermotor roda dua maupun kendaraan roda empat di negara berkembang termasuk di Indonesia, meningkat secara tajam (Asri dkk, 2012). Hal ini membawa kepada kondisi perilaku lalu lintas pada jaringan jalan perkotaan menjadi lalu lintas yang heterogen (Hustim dkk., 2015). Berbagai perilaku lalu lintas heterogen telah dan masih memberikan dampak lalu lintas yang signifikan berupa tingginya kejadian kecelakaan lalu lintas di jalan-jalan 
perkotaan di Indonesia (Halim, dkk., 2017), dan meningkatnya waktu tempuh perjalanan kendaraan bermotor (Sahrullah, dkk 2017). Disamping dampak terhadap lingkungan berupa polusi udara (Arafah, dkk., 2013, Aly, dkk, 2016) dan kebisingan (Lakawa dkk., 2016; Hustim dkk., 2015).

Berfokus pada upaya pengurangan resiko dan atau tingkat keparahan kecelakaan lalu lintas di Indonesia, pihak regulator telah memberlakukan kewajiban untuk menggunakan alat pengaman kepala yang berstandar, atau sering disebut dengan Helm SNI. Berbagai kajian awal telah dilakukan di beberapa kota besar di Indonesia, sejak aturan penggunaan Helm SNI ini mula diberlakukan. Namun demikian, karakteristik suku, budaya dari masyarakat Indonesia yang sangat beragam, memberikan hasil-hasil penelitian yang juga bervariatif satu wilayah dengan wilayah lainnya.

Dalam konteks memperkaya khasanah penlitian di bidang ini dan menambah perspektif tentang preferensi masyarakat pengendara sepeda motor terhadap penggunaan helm SNI, Penelitan ini bertujuan menginvestigasi preferensi dan menganalisis factor-faktor yang dapat mempengaruhi preferensi pengendara sepeda motor terhadap pemberlakuan aturan kewajiban menggunakan Helm SNI di Kota Makassar.

\section{METODE STUDI}

\section{Variabel Penelitian}

Variabel-variabel yang dipertimbangkan pada penelitian ini adalah variable endogen dan variable-variabel eksogen. Variabel endogen merupakan suatu variable terikat yang berupa preferensi pengendara sepeda motor terhadap kebijakan dan kenyamanan penggunaan helm SNI. Adapun variabel-variabel eksogen meliputi variabele-variabel karakteristik individu pengendara sepeda motor, antara lain, usia, pendidikan, pekerjaan dan penghasilan. Atribut-atribut dari setiap variable disajikan pada Tabel 1.

Tabel 1. Variabel penelitian dan atributnya

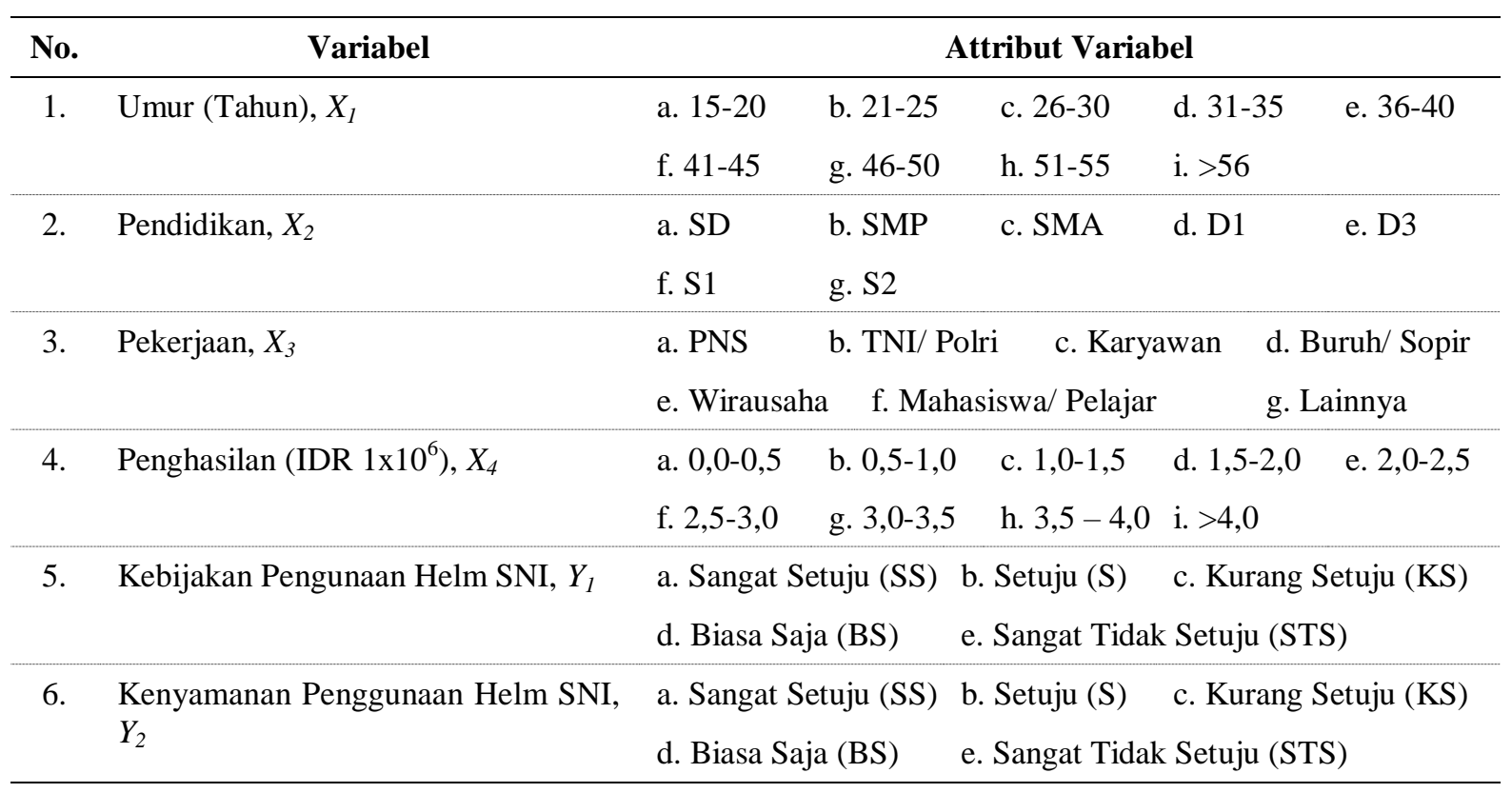




\section{Lokasi Penelitian}

Penelitian ini mengambil lokasi survei pada ruas J1. A.P. Pettrani, jalan terbesar dan terpanjang di Kota Makassar, dimana jumlah pengendara sepeda motor sangat besar dan dominan. Secara visual, lokasi penelitian disajikan pada Gambar 1.

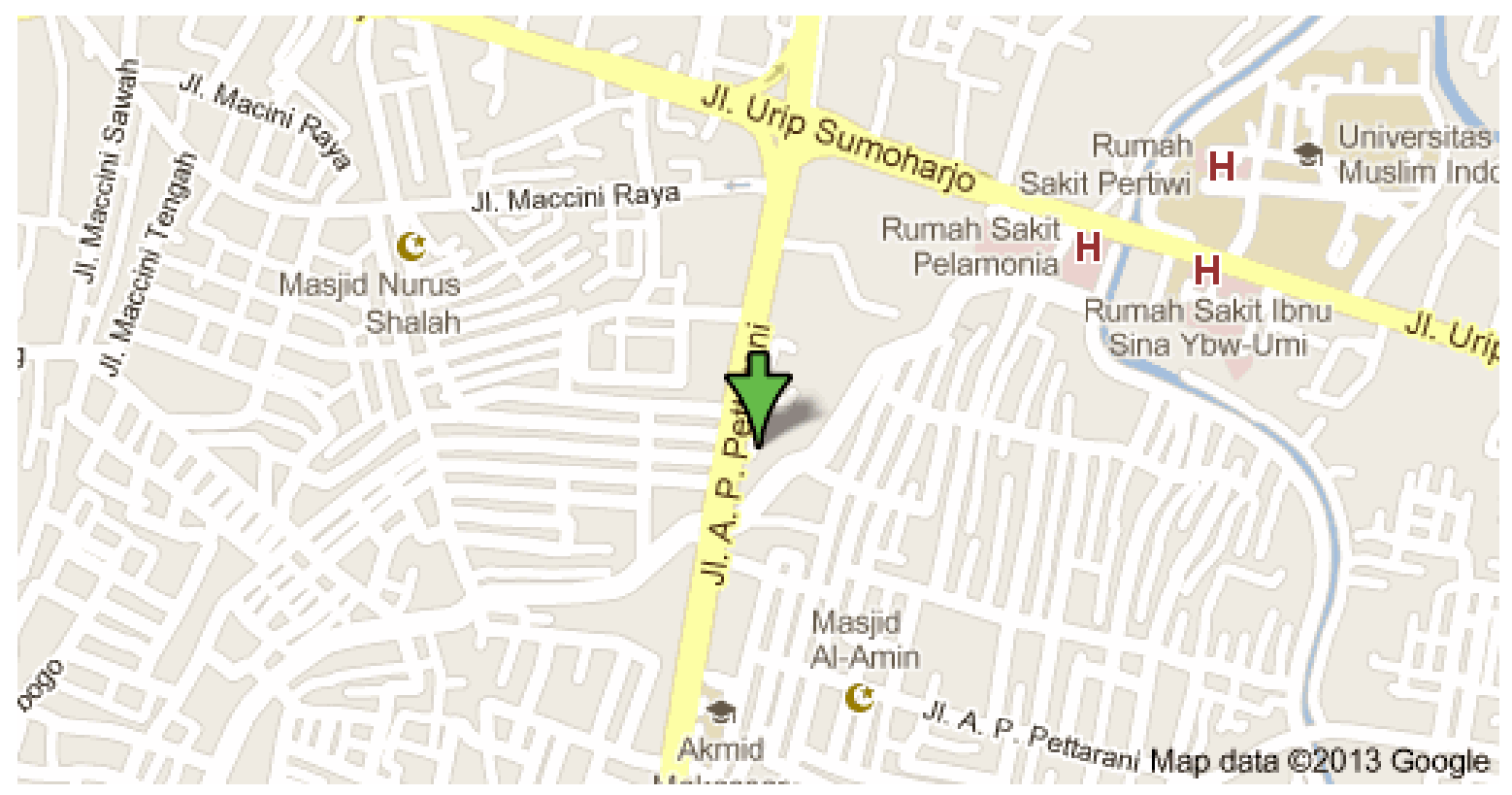

Gambar 1. Lokasi penelitian

\section{Pengumpulan Data}

Pengumpulan data menggunakan instrumen kuesioner yang memuat daftar pertanyaan kepada responden pengendara sepeda motor sebagaimana variabel-variabel dan atribut variabel yang ada pada Tabel 1 .

Metode pengumpulan data yang digunakan pada studi ini adalah metode wawancara langsung oleh surveyor kepada responden pengendara sepeda motor. Wawancara dilakukan dengan menggunakan instrumen kuesioner yang telah didisain.

Pada studi ini, dalam rangka memudahkan pelaksanaan survei wawancara terhadap pengguna kendaraan sepeda motor dan mempertimbangkan untuk tidak mengganggu kelancaran arus lalu lintas pada ruas jalan lokasi studi (Jl. AP. Pettarani), maka survei wawancara dilakukan pada Stasiun Pengisian BBM Umum (SPBU) yang berlokasi disepanjang J1. AP. Pettarani. Dalam hal ini, terdapat 3 lokasi SPBU yang digunakan sebagai tempat pelaksanaan survei wawancara. Kegiatan wawancara terhadap pengendara sepeda motor dilakukan ketika pengendara sepeda motor sementara menunggu saat melakukan pengisian bahan bakar di SPBU. Waktu pelaksanaan survei dilakukan pada periode puncak pagi lalu lintas pada tanggal 17 April 2014, dimana setiap SPBU dilakukan survei wawancara terhadap sejumlah 320 responden yang dipilih secara acak ketika masuk mengisi BBM di SPBU. Dengan demikian, terdapat total sampel sebanyak 960 responden.

\section{Metode Analisis}

Analisis data survei dilakukan dalam 2 tahapan. Tahap pertama adalah analisis dengan pendekatan statistik deskriptif terhadap data-data karakteristik pengendara sepeda motor, 
dan keterhubungan antar karakteristik pengendara sepeda motor. Tahap kedua adalah analisis signifikansi variabel terhadap preferensi penggunaan Helm SNI, baik preferensi terhadap kebijakannya, maupun preferensi terhadap kenyamanannya, dengan menggunakan pendekatan model regresi logistik jenis model multi-nomial logit (MNL). Dalam hal ini, pendekatan model MNL yang diadopsi adalah sebagaimana telah digunakan oleh Koppelman dan Bhat (2006) dan Wedagama dan Dissanayake (2010), serta Asri dkk (2011).

\section{HASIL DAN PEMBAHASAN}

\section{Karakteristik Sebaran Data Pengguna Sepeda Motor}

Karakteristik sebaran data pengguna sepeda motor untuk setiap atribut variable disajikan pada Tabel 2.

Tabel 2. Karakteristik sebaran data untuk setiap atribut variable

\begin{tabular}{|c|c|c|c|c|}
\hline \multirow{2}{*}{ No. } & \multirow{2}{*}{$\begin{array}{r}\text { Variabel } \\
\text { Umur (Tahun), } X_{I}\end{array}$} & \multicolumn{3}{|c|}{ Frekuensi (\%) } \\
\hline & & a. $15-20(20,4)$ & d. $31-35(13,2)$ & g. $46-50(5,5)$ \\
\hline & & b. $21-25(22,7)$ & e. $36-40(8,3)$ & h. $>50(4,0)$ \\
\hline & & c. $26-30(19,7)$ & f. $41-45(6,2)$ & \\
\hline \multirow[t]{3}{*}{2.} & Pendidikan, $X_{2}$ & a. $\mathrm{SD}(1,7)$ & d. D1 $(1,5)$ & g. S2 $(1,9)$ \\
\hline & & b. SMP $(6,4)$ & e. D3 $(5,7)$ & \\
\hline & & c. SMA $(49,9)$ & f. S1 $(32,9)$ & \\
\hline \multirow[t]{4}{*}{3.} & Pekerjaan, $X_{3}$ & a. PNS $(14,0)$ & \multicolumn{2}{|c|}{ e. Wirausaha $(10,8)$} \\
\hline & & b. TNI/Polri $(1,3)$ & \multicolumn{2}{|c|}{ f. Mahasiswa/Pelajar $(34,2)$} \\
\hline & & c. Karyawan $(26,8)$ & \multicolumn{2}{|c|}{ g. Lainnya $(9,1)$} \\
\hline & & d. Buruh/Sopir $(3,8$ & & \\
\hline \multirow[t]{3}{*}{4.} & Penghasilan (IDR $\left.1 \times 10^{6}\right), X_{4}$ & a. $0,0-0,5(9,3)$ & d. $1,5-2,0(6,6)$ & g. $3,0-3,5(16,8)$ \\
\hline & & b. $0,5-1,0(26,5)$ & e. $2,0-2,5(21,2)$ & h. $3,5-4,0(4,5)$ \\
\hline & & c. $1,0-1,5(10,0)$ & f. $2,5-3,0(1,3)$ & i. $>4,0(3,8)$ \\
\hline \multirow[t]{2}{*}{5.} & Kebijakan Pengunaan Helm SNI, $Y_{1}$ & a. SS (43) & c. KS (8) & e. STS (0) \\
\hline & & b. S (49) & d. BS (0) & \\
\hline \multirow[t]{2}{*}{6.} & Kenyamanan Penggunaan Helm SNI, $Y_{2}$ & a. SS (35) & c. KS (13) & e. STS (0) \\
\hline & & b. S (52) & d. BS (0) & \\
\hline
\end{tabular}

Tabel 2 memperlihatkan bahwa atribut dominan untuk variabel umur pengguna sepeda motor adalah kategori 15-20 tahun dan kategori 21-25 tahun yang memiliki prosentase 20,4\% dan 22,7\% secara berurut. Untuk karakteristik Pendidikan, terlihat bahwa dominan pengguna sepeda berpendidikan SMA dan Sarjana S1. Dari segi karakteristik pekerjaan, atribut dominan adalah pengguna sepeda motor berprofesi sebagai Mahasiswa/Pelajar, disusul oleh Karyawan dan PNS. Berdasarkan karakteristik penghasilan terlihat bahwa dominan pengendara sepeda motor memiliki penghasilan 0,5-1,0 juta rupiah, dan 2,0-2,5 juta rupiah. 
Lebih jauh, Tabel 2 memperlihatkan komposisi preferensi pengendara sepeda motor terhadap penggunaan Helm SNI, baik untuk kebijakan maupun untuk kenyamanan penggunaannya. Preferensi pengendara sepeda motor terhadap kebijakan penggunaan Helm SNI adalah didominasi oleh preferensi setuju dan sangat setuju secara berimbang. Namun demikian masih terdapat porsi kecil yang menyatakan kurang setuju. Hal ini sejalan pula dengan preferensi pengguna sepeda motor terhadap kenyamanan penggunaan Helm SNI.

Untuk menganalisis lebih jauh secara deskriptif terhadap kedua jenis preferensi pengendara sepeda akan penggunaan Helm SNI, maka pada sub-bagian berikut dilakukan analisis deskriptif pola hubungan antara persepsi pengendara sepeda motor terhadap kebijakan penggunaan Helm SNI, dan hubungan antara persepsi pengendara sepeda motor terhadap kenyamanan penggunaan Helm SNI.

\section{Persepsi Pengendara Sepeda Motor terhadap Kebijakan Penggunaan Helm SNI}

Analisis deskriptif pola hubungan antara persepsi pengendara sepeda motor terhadap kebijakan penggunaan Helm SNI disajikan secara visual pada Gambar 2.

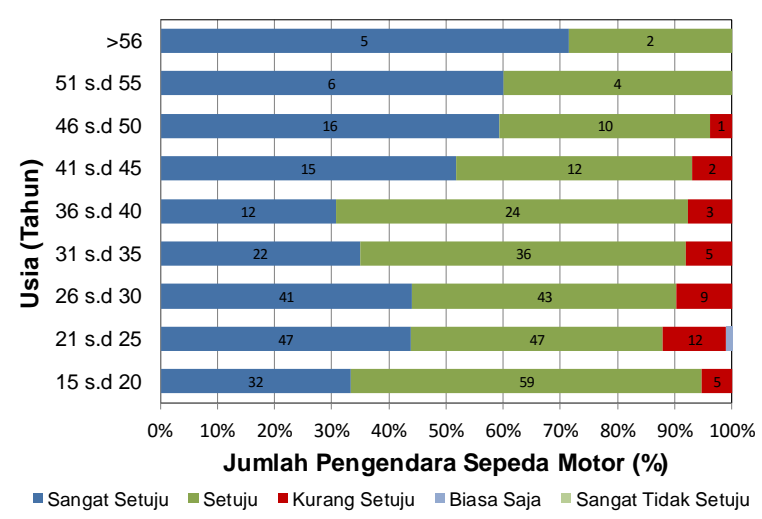

a. Usia

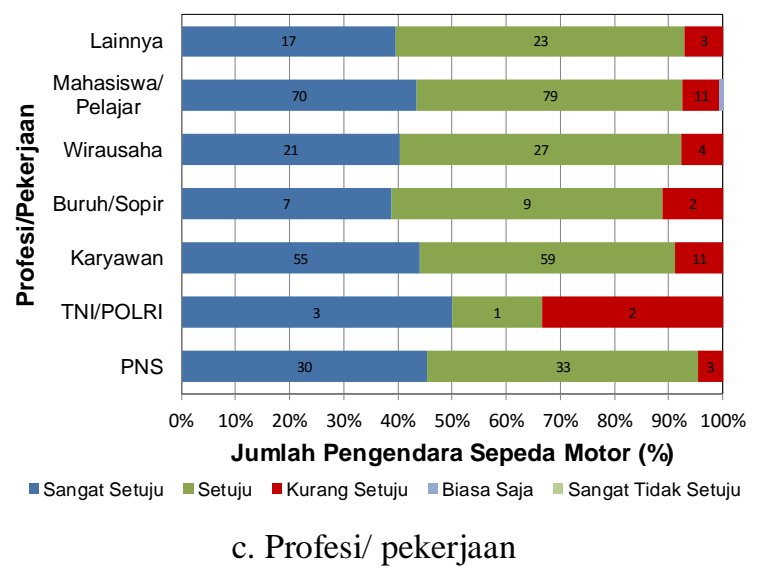

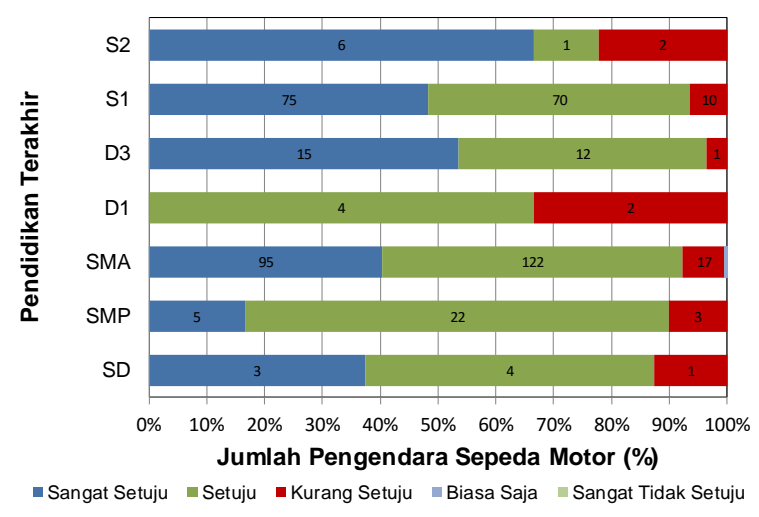

b. Pendidikan terakhir

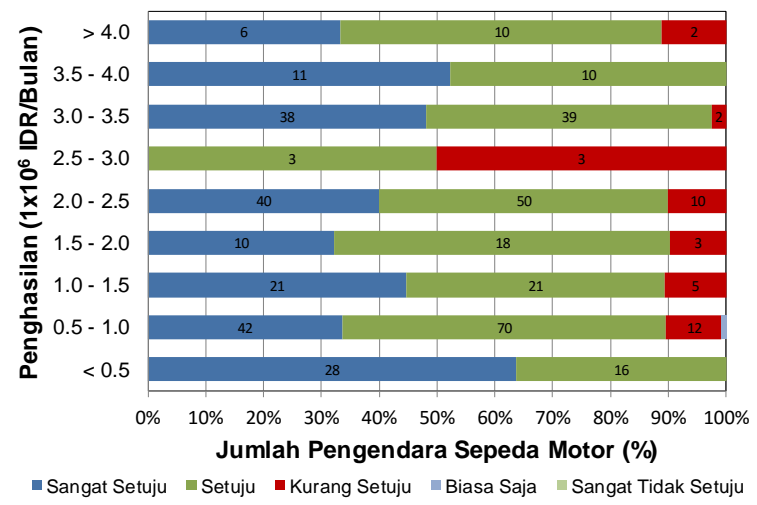

d. Penghasilan

Gambar 2. Persepsi Vs Karakteristik pengendara SM Terhadap kebijakan helm SNI 


\section{Preferensi Pengendara Sepeda Motor Terhadap Kenyamanan Penggunaan Helm SNI}

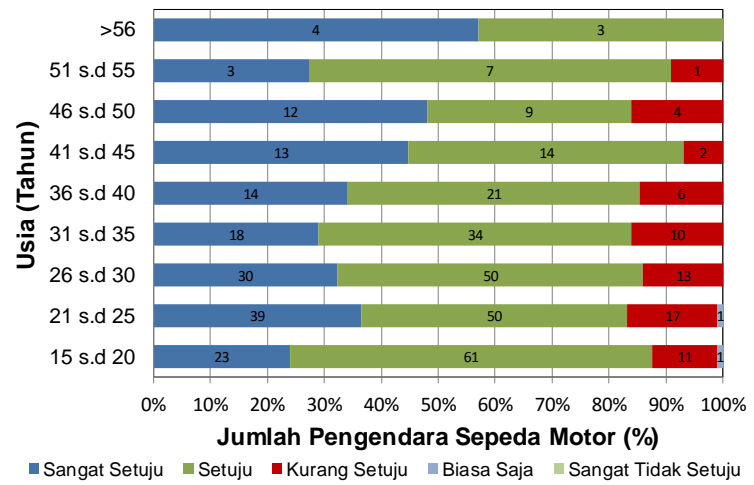

a. Usia

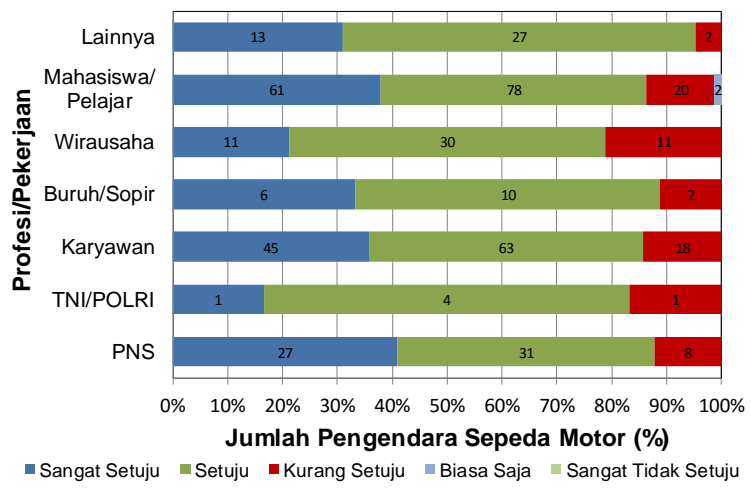

c. Profesi/ pekerjaan

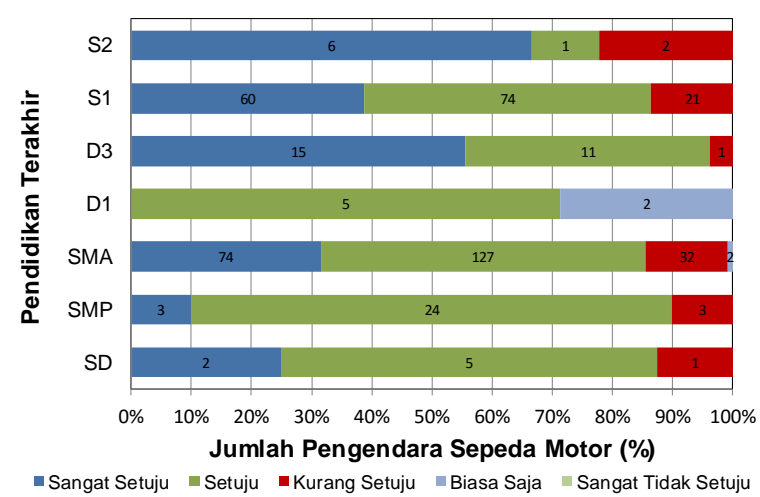

b. Pendidikan terakhir

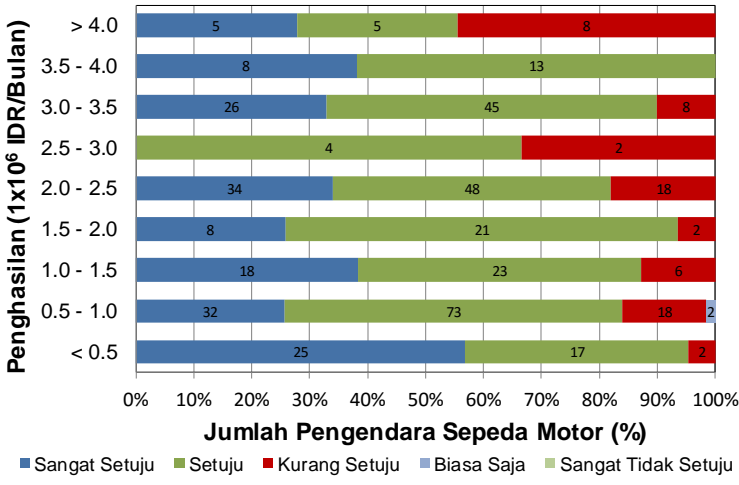

d. Penghasilan

Gambar 3. Persepsi Vs Karakteristik pengendara SM terhadap kenyamanan helm SNI

Analisis deskriptif pola hubungan antara preferensi pengendara sepeda motor terhadap kenyamanan penggunaan Helm SNI disajikan secara visual pada Gambar 3.

\section{Analisis Signifikansi Karakteristik Pengguna Sepeda Motor terhadap Preferensi Penggunaan Helm SNI}

Berdasarkan analisis deskriptif pola hubungan antara persepsi pengendara sepeda motor terhadap kebijakan dan kenyamanan penggunaan helm SNI, maka variabel endogen pada analisis persepsi pengendara dengan menggunakan pendekatan model multi-nomial logit (MNL), dibagi atas 3 kategori saja, yaitu "sangat setuju", "setuju", dan kurang setuju". Hasil estimasi model MNL disajikan pada Tabel 3 dan Tabel 4 untuk preferensi kebijakan dan preferensi kenyamanan penggunaan Helm SNI secara berurutan.

Hasil-hasil estimasi model MNL untuk kedua kategori preferensi pengendara sepeda motor terhadap penggunaan Helm SNI sebagaimana disajikan pada Tabel 3 dan Tabel 4 memperlihatkan bahwa variable umur dan variable Pendidikan merupakan dua variable yang cukup signifikan mempengaruhi kedua kategori preferensi pengguna sepeda motor di Kota Makassar. 
Tabel 3. Hasil estimasi Model MNL untuk preferensi kebijakan helm SNI

\begin{tabular}{|c|c|c|c|c|c|c|c|}
\hline \multirow{3}{*}{ Variables } & \multirow{3}{*}{$\begin{array}{l}\text { Para- } \\
\text { meters }\end{array}$} & \multicolumn{6}{|c|}{$\begin{array}{c}\text { Preferensi Pengendara terhadap Kebijakan Penggunaan } \\
\text { Helm SNI }\end{array}$} \\
\hline & & \multicolumn{3}{|c|}{ Sangat Setuju } & \multicolumn{3}{|c|}{ Setuju } \\
\hline & & B & Std. Err. & $\mathbf{P}>[\mathbf{z}]$ & B & Std. Err. & $\mathbf{P}>[\mathbf{z}]$ \\
\hline Umur (Tahun), $X_{1}$ & $\beta_{\mathrm{X} 1}$ & 0.193 & 0.044 & 0.000 & 0.189 & 0.045 & 0.000 \\
\hline Pendidikan, $X_{2}$ & $\beta_{\mathrm{X} 2}$ & 0.410 & 0.180 & 0.023 & 0.413 & 0.182 & 0.021 \\
\hline Pekerjaan, $X_{3}$ & $\beta_{\mathrm{X} 3}$ & -0.034 & 0.173 & 0.847 & -0.031 & 0.170 & 0.843 \\
\hline Penghasilan (IDR $\left.1 \times 10^{6}\right), X_{4}$ & $\beta_{\mathrm{X} 4}$ & 0.000 & 0.000 & 0.131 & 0.000 & 0.000 & 0.135 \\
\hline Konstanta & $\beta_{o}$ & -5.555 & 1.559 & 0.000 & -5.551 & 1.553 & 0.000 \\
\hline Number of observation & & & & & & & 471 \\
\hline Likelihood ratio, $\rho^{2}$ : & & & & & & & 0.515 \\
\hline
\end{tabular}

Tabel 4. Hasil estimasi Model MNL untuk preferensi kenyamanan helm SNI

\begin{tabular}{|c|c|c|c|c|c|c|c|}
\hline \multirow{3}{*}{ Variables } & \multirow{3}{*}{$\begin{array}{l}\text { Para- } \\
\text { meters }\end{array}$} & \multicolumn{6}{|c|}{$\begin{array}{c}\text { Preferensi Pengendara terhadap Kenyamanan Penggunaan } \\
\text { Helm SNI }\end{array}$} \\
\hline & & \multicolumn{3}{|c|}{ Sangat Setuju } & \multicolumn{3}{|c|}{ Setuju } \\
\hline & & B & Std. Err. & $\mathbf{P}>[\mathbf{z}]$ & $\mathbf{B}$ & Std. Err. & $P>[z]$ \\
\hline Umur (Tahun), $X_{1}$ & $\beta_{\mathrm{X} 1}$ & 0.190 & 0.049 & 0.000 & 0.186 & 0.042 & 0.000 \\
\hline Pendidikan, $X_{2}$ & $\beta_{\mathrm{X} 2}$ & 0.412 & 0.185 & 0.021 & 0.413 & 0.182 & 0.024 \\
\hline Pekerjaan, $X_{3}$ & $\beta_{\mathrm{X} 3}$ & -0.031 & 0.176 & 0.842 & -0.035 & 0.174 & 0.841 \\
\hline Penghasilan (IDR $1 \times 10^{6}$ ), $X_{4}$ & $\beta_{\mathrm{X} 4}$ & 0.000 & 0.000 & 0.136 & 0.000 & 0.000 & 0.132 \\
\hline Konstanta & $\beta_{\mathrm{o}}$ & -5.550 & 1.553 & 0.000 & -5.556 & 1.550 & 0.000 \\
\hline Number of observation & & & & & & & 471 \\
\hline Likelihood ratio, $\rho^{2}$ : & & & & & & & 0.509 \\
\hline
\end{tabular}

\section{KESIMPULAN}

Studi ini telah menginvestigasi dan mengeksplorasi preferensi pengendara sepeda motor di Kota Makassar terhadap penggunaan Helm SNI, baik dari sisi preferensi akan kebijakannya, maupun dari sisi preferensi akan kenyamanan Helm SNI. Melalui metode wawancara berbasis instrumen kuesioner, berbagai hasil data karakteristik dan preferensi pengendara sepeda motor dianalisis secara statistik deskriptif dan kuantitatif dengan pendekatan model multi-nomial logit (MNL).

Karakteristik umur dan pendidikan terakhir pengendara responden menjadi dua faktor utama yang cukup mempengaruhi preferensi pengendara sepeda motor terhadap kebijakan dan kenyamanan penggunaan Helm SNI. Kedua variable ini sangat berkaitan erat dalam hal stratafikasi pengguna sepeda motor. Disisi lain, karakteristik pekerjaan dan penghasilan 
dari pengguna sepeda motor terlihat masih kurang memberikan pengaruh terhadap preferensi pengguna sepeda motor dalam penggunaan Helm SNI.

Hasil studi sangat bermanfaat dalam hal memberikan informasi terkait potensi strategi yang perlu dilakukan oleh Pemangku Kepentingan dalam rangka implementasi aturan tertib berlalu lintas untuk pengendara sepeda motor dalam hal penggunaan Helm SNI dana tau berbagai moda-moda keselamatan berlalu lintas di Kota Makassar pada khususnya, dan di kota-kota besar di Indonesia pada umumnya.

\section{UCAPAN TERIMA KASIH}

Ucapan terima kasih disampaikan kepada Sdr. Muhammad Guntur, ST. (Alumni S1 Departemen Teknik Sipil Fakultas Teknik Universitas Hasanuddin) yang telah membantu dalam kegiatan pengumpulan dan analisis data pada studi ini. Ucapan terima kasih juga disampaikan kepada Almarhum Ir. Arifin Asri, MSi., yang telah turut berkontribusi memberikan pandangan dan diskusi dalam arah analisis dari kegiatan penelitian ini.

\section{DAFTAR PUSTAKA}

Asri, A., Ramli., M. I., Samang, L. 2012. A Study on Motorcycle Ownership of Residential Households in Makassar. Proceeding of The $15^{\text {th }}$ FSTPT International Symposium, STTD Bekasi, November 23-24, 2012.

Asri, A., Ramli, M. I., Samang, L. 2011. Motorcyclist Acceptability on Road Safety Policy: Motorcycle Exclusive Lane in Makassar. Proceeding of the 15th FSTPT International Symposium, Pekanbaru, November 11-13, 2011.

H Halim, SA Adisasmita, MI Ramli, SH Aly, 2017, The Pattern of Severity of Traffic Accidents on Traffic Conditions Heterogeneous, International Journal of Civil Engineering and Technology (IJCIET) 8 (4), 1720-1729.

I Lakawa, L Samang, M Selintung, M Hustim, 2016, Factors Affecting Traffic Noise Based On Road Environment Aspects, International Journal of Engineering and Science Applications 2 (2), 117-124.

Koppelman, F.S., and Bhat, C. 2006. A Self Instructing Course in Mode Choice Modeling: Multinomial and Nested Logit Model. U.S. Department of Transportation Federal Transit Administration.

M Hustim, MI Ramli, SH Aly, 2015, An Investigation on the Sound Power Level of Vehicles in Makassar City, Proceedings of the Eastern Asia Society for Transportation Studies 10.

Sahrullah, MI Ramli, N Ali, R Rahim, 2017, A Travel Time Estimation Model of Private Cars in Urban Arterial Roads Based on Heterogeneous Traffic, International Journal of Civil Engineering and Technology 8 (7), 676-685.

SH Aly, MI Ramli, 2016, A development of MARNI 12.2 model: A calculation tool of vehicular emission for heterogeneous traffic conditions, Journal of Engineering and Applied Sciences 11 (1), 43-50.

Wedagama, D.M.P., and Dissanayake, D. 2010. Analysing Motorcycle Injuries on Arterial Roads in Bali Using Multinomial Logit Model. Journal of the Eastern Asia Society for Transportation Studies, Vol.8, pp. 1892-1904. 
Traffic Accident Research Centre

This page is blank 